\begin{tabular}{|r|c|c|}
\hline Received: September 2017 & Accepted: January 2018 & Published: April 2018 \\
\hline \multicolumn{2}{|c|}{ Article DOI: $\underline{\text { http://dx.doi.org/10.24903/sj.v3i1.138 }}$} \\
\hline
\end{tabular}

\title{
Cross Cultural Rhetoric Awareness of Undergraduate Thesis Introduction Section Written by Acehnese EFL Students
}

\author{
Bustami Usman \\ Syiah Kuala University \\ bustami55@yahoo.com \\ Novalia Rizkanisa \\ Syiah Kuala University \\ novalia.rizkanisa@gmail.com \\ Iskandar Abdul Samad \\ Syiah Kuala University \\ $\underline{\text { Iskandar.abdul.samad@unsyiah.ac.id }}$ \\ Asnawi Muslem \\ Syiah Kuala University \\ drasnawi@unsyiah.ac.id
}

\begin{abstract}
This study investigated cross cultural rhetoric awareness of introduction section by Acehnese EFL students. This study aimed at describing the rhetorical pattern and determine the cross cultural rhetoric awareness by looking at the rhetorical pattern in Introduction section. A qualitative method and content analysis were used in this study which analyzed the Introduction section. The data of this research was English undergraduate thesis written by ten Acehnese students as the documentation was applied as the instrument. The data were collected from two Islamic institutes in Aceh. The research was conducted by using documentation analysis. The result of the analysis demonstrated that the English writings by Acehnese students maintained the inductive style and the idea of the paragraph is circular. However, the use of markers is enough to be considered. The conclusion led to the rhetorical pattern of the Acehnese students which is in oriented style. Indeed, the implication of the finding showed that the students' cross cultural rhetoric awareness toward English writing convention, especially in academic writing, is low.
\end{abstract}

Keywords: Cross cultural rhetoric, Thesis Introduction section, Acehnese EFL students 


\section{INTRODUCTION}

This study is purposefully done to analyze the writing of Acehnese EFL students. The exact target of analysis is on investigating the students' awareness of cross cultural rhetoric in Introduction section. As an essential skill, academic English writing has been a compulsory subject for English Department students in Indonesia. In fact, the academic writing, especially an introductory part is not solely the application of grammatical rules, but it also requires cultural writing convention. Many non-native speakers were expected to be able to fulfill the academic reader criteria of target language and proper rhetorical structure of text as revealed by Bennui (2008, p. 75) that "even if they use the correct grammar and the relevant vocabulary, non-native students' target language exhibits foreign-sounding structure that belong to the first language". Hence, some knowledge about the rhetorical pattern bound up with the target culture and its audience's expectation is of paramount important (Hamadouche, 2013). Students' understanding of rhetorical structure of a communicative event, in this case is writing, helps them to perform well in presenting it (Samad \& Adnan, 2017) to meet the academic readers' expectation.

As aforementioned explanation, initiated by Robert Kaplan, an American applied linguist, with his idea as follows: "contrastive rhetoric maintains that language and culture are cultural phenomena" (Hyland, 2012, p. 46). It is a study about how a person's first language and culture influence his/her writing in foreign/second language. This study becomes a leading role for the next numerous studies related to the field of cross-cultural rhetoric. Xing, Wang, and Spencer (2008) conducted a brilliant research toward the writing rhetorical pattern of Chinese and English speakers. The result indicated that the problem on the Chinese speakers occur mostly on paragraph organization. This happens due to lack of understanding of the way of organizing a paragraph in their own writing. Moreover, other researchers, such as Crawford et al. (2013) did the different study concerning to a contrastive rhetoric. They also concerned of the perception of identity in written academic English in central Mexico. More specifically, this study did not only analyze the writing, but they also did an open interview. The result showed that though the students have a strong identity with English, the actual writing is more in tune with the convention of Spanish.

In Indonesian context, the study was conducted by Marcellino (2006). He found the tendency of indirectness in Indonesian students' writing. Then, the non-linearity that characterizes Indonesian writers' text is due to the students' strategy of translating ideas, sentences and expressions from his native language into English. Similarly, Arsyad (2000) 
examined the organizational structure of argumentative essay done by the Indonesian students is different from the NES (Native English Speaker), which is due to the cultural background. Therefore, an awareness of similarities and differences in the particular cultures especially in writing will help students to write more effectively. As aforementioned, this study attempted to answer a research question formulated as follows: What form of rhetorical pattern does the undergraduate Acehnese EFL students produce in Introduction section? Then, this research intended to find out the rhetorical pattern reflected in introduction section written by Acehnese EFL students.

\section{Cross-Cultural Rhetoric}

In particular, writing is commonly known as a complicated skill that has to be learned by students. Thus, this can be a particular challenge for them. In English teaching and learning, studying English culture is not only taking the structure of the language but also taking the culture in it. It gives students who have English as additional language a reason to study the target language meaningfully (Genc \& Bada, 2005). By understanding the target language, it is easier to the students to accommodate language because each culture shapes the convention of written discourse. Therefore, understanding across culture is of paramount importance in studying a language. It has been proved by some studies on writing, one of them that have been reviewed by Cahyono (2001) in his article. His review exhibited that students of ESL/EFL have a tendency in translating their L1 words into English by using the language patterns and based on their first language and culture convention they have.

\section{Contrastive Rhetoric}

"Cultural thought patterns in intercultural education" is a renowned essay which was pioneered by Robert Kaplan in 1966 and nowadays commonly known as contrastive rhetoric. The essay is as enlightenment way toward the rhetorical and organizational problem faced by second/foreign language learners in writing English. This framework is also offered to highlight cultural differences in how texts are organized (Helal, 2013). Kaplan claimed that different rhetorical patterns will be yielded by the speakers of different languages. Surprisingly, these patterns often become the negative transfer in English written text. These differences in rhetorical patterns may cause difficulties for second/foreign language learners. Therefore, the area of contrastive rhetoric studies has a significant impact on the teaching of writing in both ESL and EFL classes. Similarly, Nunan (1999) revealed that the result of imposing the target language rhetorical patterns can be enlightening for students to be made aware of differences between their own language and their target language/English. Thus, 
contrastive rhetoric has informed of writing in EFL/ESL context, particularly the area of English for academic writing in university setting.

English, Semitic, Oriental, Romance and Russian are five major language families that were become the Kaplan's data in his essays. The result of his essay is graphically represented in the following manner or it is commonly known as "The Doodles" as follows:

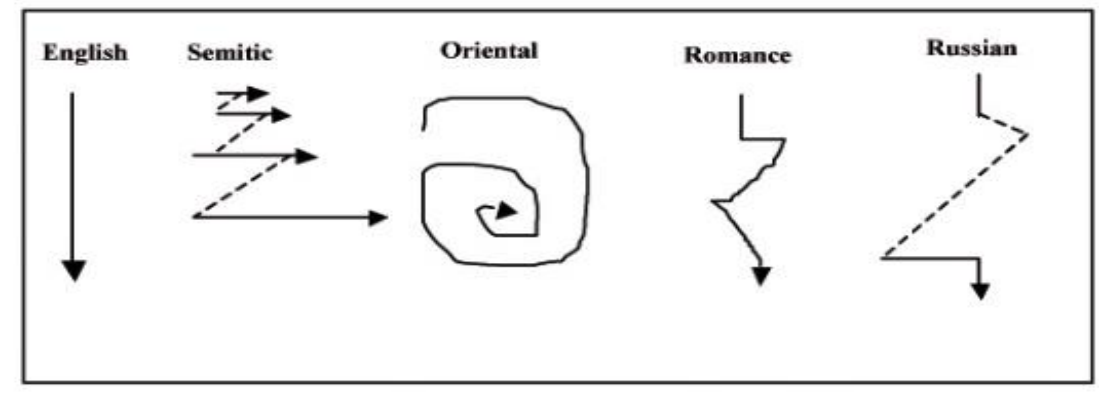

Figure 1. Rhetorical structure. (Kaplan, 1966, p. 20)

Linearity of the organizational pattern is represented in English doodle. It described as a straight and vertical line where it usually starts from main idea (topic statement) followed by supporting detail to relate it into the other ideas. Importantly, cohesion and coherence also become the main concern in English written text. CR analysis was also conducted by Sabzhevari and Sagedhi (2014) in their study about the analysis of the news report between Iranian and American. Then, another researcher, Li (2011) conducted a research on internship cover letters written by students in two different countries, Taiwan and Canada. Each research actually has different scopes, but the result is quite similar in which non-native English speakers remain maintaining their mother tongue writing convention into English writing. In short, the major obstacles in adapting a new culture are because of their unfamiliarity and unawareness toward the language. In accordance to Kaplan's analysis, Researchers, Xing et al (2008) and Incecay (2015) formulated the rhetorical patterns as follows.

\section{Placement of Thesis Statement (Inductive vs. Deductive)}

As stated by Magginson (2007) that "thesis statement is a sentence summarizing the fundamental argument of an essay." Inductive and deductive became the main concern in identifying the placement of the thesis statement. Actually, the main idea or thesis statement is put in the first followed by the supporting detail. That was the fact that the written text by Native English Speaker (NES) is deductively. In fact, written texts in China exhibit the inductive style, in which the supporting detail is given first then leading the reader to the main idea at the end (Liu, 2007). 


\section{Pattern of Idea (Circularity vs. Linearity)}

Top-down and linearity style is commonly known as the criteria of English written text by native speaker of English (Cameron, 2007). They pour the main idea or theme at the beginning of essay because of their linear style of writing. Meanwhile, circularity can be identified by looking at how they arrange the topic changes in paragraphs. In fact, Asian students maintained the circularity of the idea in their written text which was no topic sentence in a paragraph or there are too many issues put within one paragraph.

\section{Metadiscourse Markers}

In the usage of metadiscourse marker, Mirshami and Allami (2008) stated that the usage of metadiscourse marker as a measuring rod in judging the quality of the written academic text. Likewise, Estaji and Vafaeimehr (2015) also agreed that one of main focus in students' written text is how proficient they are in using metadiscourse markers in their writing. In a nutshell, English written texts use metadiscourse markers to signal the relation between sentences and parts of the text. The writer has to be able regularly put the metadiscourse in the text so the reader can see how the writer intends to pour his/her idea in the text (Hyland, 2012). Then, the transition statement engaged the reader in how the parts of text are connected.

\section{Introduction Section}

The past decade has seen some studies toward the analysis of the English written text by the non-native. The data often came from essay. In particular, this study is purposefully done in analyzing introduction sections part in undergraduate thesis. Having an introduction section means that the writer has the attractive things in taking readers' attention to the written form. Similarly, Swales and Feak (2001) stated that "introduction section provides the rationale for the paper, moving from general discussion of the topic to the particular question or hypothesis being investigated ............" (p.156). Introductory part serves the main idea related to the topic in the research and it is linked and followed by the research questions later on. In fact, writing introduction is not mere writing the foundation of the research. It becomes a specter to EFL learners because the introduction section is considered a part that has to be done completely and clearly. This section becomes a determining factor in the success of the research. The research has to demonstrate the deep experience, knowledge and passion in it. 


\section{METHODOLOGY}

This research was designed qualitatively which described the rhetoric reflected in the introductory part in the undergraduate thesis. By conducting content analysis, the result is taken from a detailed examination of content from a particular body of material. Furthermore, the research subject was Acehnese students' undergraduate theses. Meanwhile, the object of the research focused on the writing content and rhetorical used by the students. The researchers collected ten undergraduate theses of English department students from two Islamic state institutes in Aceh, namely IAIN Zawiyah Cotkala Langsa and IAIN Malikusaleh Lhokseumawe. These students are coded by combination of letter and number for ethical purposes. UnT1-5 are from IAIN Zawiyah Cot Kala and UnT6-10 are from IAIN Malikulsaleh. The analysis of introduction section was only on the thesis background of the study. Finally, the research result eventually showed Acehnese students' rhetorical pattern in introduction section. Equally important, it also showed how aware the students about crosscultural rhetoric in academic written text.

\section{FINDINGS AND DISCUSSION}

The researchers analyzed the Introduction section by using Incecay's framework (2015). The analysis was only limited on background of the study part in the Introduction section. The result of the analysis is analyzed by using three criteria below. Each criterion is discussed deeply in the following sub-sections.

\section{Placement of the Thesis}

There are three placements of the thesis statement in Chinese written text: deductive style (thesis at the beginning), quasi-inductive style (thesis in the middle), and inductive style (thesis at the end). Those three placements are found in the study by Xing et al (2008). Eventually, the corpus data in this research also showed that those placements are also used in the introduction section by Acehnese students. The table below shows the placement of the thesis. 


\begin{tabular}{|c|c|}
\hline Placement of Thesis Statement & $\begin{array}{c}\text { Number of Thesis } \\
\mathbf{N}=\mathbf{1 0}\end{array}$ \\
\hline $\begin{array}{c}\text { Deductive style } \\
\text { (Thesis at the beginning) }\end{array}$ & 2 \\
\hline $\begin{array}{c}\text { Quasi-Inductive style } \\
\text { (Thesis in the middle) }\end{array}$ & 3 \\
\hline $\begin{array}{c}\text { Inductive style } \\
\text { (Thesis at the end) }\end{array}$ & 5 \\
\hline
\end{tabular}

Table 1. Placement of the Thesis

The table1 above shows two Acehnese students used thesis statement deductively. Then, they tend to write the thesis statement in the middle (quasi-inductive) which is used in three Introductions. Moreover, two Introductions of Acehnese students used it inductively. Further, to give more insights to the findings, the researcher presents the examples toward the placement of the thesis. There is a term that will be stated in this research that is UnS which is a code for the corpus data short for Undergraduate Thesis. Below is the undergraduate thesis excerpt of UnT 6.

\section{Deductive Style (Thesis at the beginning)}

Title: The Correlation between English Teacher Professionalism and Students' Achievement in Learning English to the First Year Students of SMPN 7 Lhokseumawe.

Learning achievement is attained after completing learning process. It is shown by score that students gained from test of each lesson that they already studied before. Of course, every student is always expected the great score and maximum achievement in his/her lesson and test.

Within achievement process, learning achievement is absolutely affected by many factors and one of them is teacher professionalism factor. Because learning process is affected by teacher professionalism, so the improving of teacher resources is unaffordable thing to do. Teacher professionalism is meaning that the teacher resource is adequate, having competence in his/her subject to teach, and able to improve students' achievement in learning. According to National Act of Education (Undang-Undang No.14/ 2005) about teacher and lecturer as mentioned in Chapter I General Qualification, verse 1: "Teacher is professional educator with main duty is educating, supervising, directing, training, assessing and evaluating the learners of basic and middle education."

The text above is enough to be considered as the example for the thesis statement at the beginning because the thesis statement that the student put almost at the beginning. For the next thesis, it is the excerpt thesis of UnT 3 which showed the placement of thesis in quasi-inductive style. 


\section{Quasi-Inductive Style (Thesis in the Middle)}

The thesis below exhibits the placement of the thesis in the middle. The excerpt is presented below which belongs to UnT 8 .

Title: The Correlation Between Students' Curiosity in Learning and Their English Achievement" (A Correlational Study at Second Grade of SMKN 4 Lhokseumawe).

Students will get well English achievement with curiosity. Kashdan maintain that recently, curiosity is defined as a positive emotional-motivational system associated with the recognition, persuit, and self-regulation of novel and challenging opportunities. Curiosity is an emotion related to natural inquisitive behavior such as exploration, investigation, and learning. As we know curiosity is one of important thing in teaching learning for students which make classroom situation active and attractive.

However currently most of students are lack of curiosity in learning that proved when teacher explained the lesson they did not give more attention. This was apprehensive condition. With huge curiosity, it will raise students' interest in studying English. Fostering students' curiosity is challenge to the educator in order to create creative and active teaching learning. So that curiosity can make students more interest in studying not only English but also all subject they studying at school.

SMKN 4 Lhokseumawe is known as one school that admitted as vocational school that pioneer of international starndarizing school (RSBI). So with that title they properly applied full English in teaching learning. Because it was demanded as one of the vocational school that pioneer of international standarizing school. It can be motivated all students being curious in learning particularly in English

From the excerpt above, it can be seen that undergraduate students in Aceh locate thesis statement mostly in the middle of their introductory part. Next, the example is the excerpt of thesis statement which is located at the beginning or at the end.

\section{Thesis at the End (Inductive)}

The excerpt is presented below which belongs to UnT 10 .

Title: The Effectiveness of Active Knowledge Sharing Strategy in teaching the first grade students in understanding narrative text at SMAN 1 Geuredong Pase.

Teacher does not only act as controller and facilitator, but also as motivator. In this case, teacher can use many methods or strategies to attract students' attention. To improve students' interest, the teachers can use various methods or strategies. However, all teachers wanted their students happy and can study well and seriously without feeling bored, lazy and difficult to understand the subjects. The big problem for teachers is when they teach, the students give less attention to her or him and to the subject being taught.

In order to make students easy in understanding narrative text, the researcher tried to apply Active Knowledge Sharing Strategy in teaching the first grade students of SMAN 1 Geuredong Pase. Through applying this strategy in learning would encouraged students not only in receiving the lessons but also in finding the process of 
the subject matter through knowledge sharing with their peers. Students can share their knowledge through the process of sharing, so that they are easy to remember the material being studied. Based on the above background, the researcher would conduct "The Effectiveness of Active Knowledge Sharing Strategy in teaching the first grade students in understanding narrative text at SMAN 1 Geuredong Pase."

The example above represented the inductive style done by Acehnese students. They tent to write their English thesis statement inductively. For the next analysis, pattern of idea seems important to be analyzed which is discussed below.

\section{Pattern of Idea}

The typical characteristic of English rhetoric is linear and circular (Xing et al, 2008). The circularity of the idea in the written text tends to be used by the students where their L1 is not English. In fact, it is also outwardly done by the Acehnese students in this research that is shown in the Table2 below.

\begin{tabular}{|c|c|}
\hline Patterns of Idea & $\mathbf{N}=\mathbf{1 0}$ \\
\hline Linear & 2 \\
\hline Circular & 8 \\
\hline
\end{tabular}

Table 2. Pattern of idea

Ten introductions were analyzed in this research. There is only two introductory parts that has the linearity of the idea which is served below. The excerpt below belongs to UnT 6 .

Title: The Correlation between English Teacher Professionalism and Students' Achievement in Learning English to the First Year Students of SMPN 7 Lhokseumawe.

Learning achievement is attained after completing learning process. It is shown by score that students gained from test of each lesson that they already studied before. Of course, every student is always expected the great score and maximum achievement in his/her lesson and test.

Within achievement process, learning achievement is absolutely affected by many factors and one of them is teacher professionalism factor. Because learning process is affected by teacher professionalism, so the improving of teacher resources is unaffordable thing to do. Teacher professionalism is meaning that the teacher resource is adequate, having competence in his/her subject to teach, and able to improve students' achievement in learning. According to National Act of Education (Undang-Undang No.14/ 2005) about teacher and lecturer as mentioned in Chapter I General Qualification, verse 1: "Teacher is professional educator with main duty is educating, supervising, directing, training, assessing and evaluating the learners of basic and middle education." 
The introduction above exhibits the linearity pattern. The pattern of idea is clear enough, but it still stated the general statement at the first. By knowing the placement of the thesis which is put deductively in this introduction, then it determined this introduction exhibits the linearity. Conversely, eight theses shared the circularity of the idea in the introduction section. Then, most Acehnese students put the thesis statement clearly in the middle of the text and at the end of the text. Below is the example of the thesis which belongs to UnT 7.

Title : The using STAD method in improving students writing descriptive paragraph to the tenth grade students of MAS Ulumul Qur'an Langsa"

The study applies Student Team-Achievement Divisions (STAD) in teaching descriptive text since this technique is simple and suitable for teaching reading. Besides, this is also the first time for writer to use this kind of technique. According to Slavin who states that "STAD is the simplest and the best technique for teachers who use cooperative learning method for the first time". Student Team-Achievement Divisions (STAD) is a Cooperative learning strategy in which small groups of learners with different levels of ability work together to accomplish a shared learning goal. Usually students are assigned four to five members in teams that mixed in performance level, gender, and ethnicity.

Furthermore, writing is a skill to expose fact and ideas in effective and organized way. It means that writing is considered as a means of training students to think logically in English. The rationale behind the activities is to find out the effective way in teaching writing English. According to the educational unit - oriental curriculum 2006 students in grade IX are expected to be able to write several texts. One of them is descriptive text. According to Brown Descriptive text is a text to describe objects as a particular person, place or thing. Therefore, it is really expected for the teacher to employ the STAD Method in making the good achievement for the student to write the descriptive writing and also to express and explore students' idea in making the best writing. Based on the explanation above the writer interested in conducting a research entitled "The using STAD method in improving students writing descriptive paragraph to the tenth grade students of MAS Ulumul Qur'an Langsa”

The example above exhibits the circular pattern of the idea. The excerpt above showed that many ideas are poured within one paragraph. Then, supporting details seems restricted to be developed in the text. The next analysis focuses on the coherency in the text. Coherency in the text is commonly marked by using metadiscourse markers. It will be explained below. 


\section{Metadiscourse markers}

Written Academic English is demanded to be coherent. Hence, the usage of metadiscourse marker becomes the main concern in academic writing. The table below presents the metadiscourse markers in the undergraduate theses of the Acehnese students.

\begin{tabular}{|c|c|c|c|c|c|c|c|c|c|c|c|}
\hline \multirow[b]{2}{*}{$\begin{array}{l}\overrightarrow{\overline{0}} \\
\overrightarrow{8} \\
\stackrel{8}{0}\end{array}$} & \multicolumn{11}{|c|}{ Discourse Marker } \\
\hline & : & 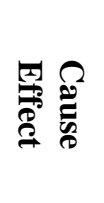 & 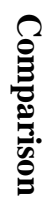 & 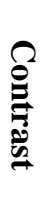 & 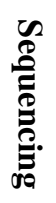 & 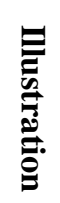 & 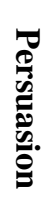 & 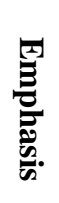 & 을. & 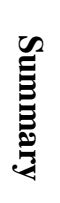 & $\stackrel{0}{0}$ \\
\hline UnT 1 & 8 & 1 & 1 & 4 & - & - & - & 1 & - & 1 & 16 \\
\hline UnT 2 & 2 & - & - & 2 & - & 1 & - & - & - & 1 & 6 \\
\hline UnT 3 & 2 & 3 & - & 2 & - & - & 1 & - & - & 3 & 11 \\
\hline UnT 4 & 3 & 4 & - & 3 & - & 3 & - & - & - & 4 & 17 \\
\hline UnT 5 & 3 & 2 & - & - & - & - & - & - & - & 1 & 6 \\
\hline UnT 6 & - & 3 & - & 3 & 2 & - & - & - & - & 1 & 9 \\
\hline UnT 7 & 1 & 2 & - & 1 & - & 1 & 1 & - & - & 4 & 10 \\
\hline UnT 8 & 3 & 1 & - & 2 & - & - & - & - & - & 1 & 7 \\
\hline UnT 9 & 1 & - & - & 2 & - & - & - & - & - & - & 3 \\
\hline UnT 10 & - & 1 & - & 2 & - & 1 & - & - & - & 2 & 6 \\
\hline
\end{tabular}

Table 3. Metadiscourse markers used by Acehnese students

Based on the table above, the researchers found that Addition, Cause Effect, Contrast, and Summary markers were often used in introduction section. Furthermore, the researchers found that comparison, sequencing, persuasion, emphasis and opinion are rarely used by the Acehnese students. The researchers assumed some reasons why they avoid using those markers. Firstly, their inability in comparing the previous studies becomes the obstacles in using this kind of sign post. Then, Acehnese students do not accustom in creating the text based on their opinion. Equally, their unfamiliarity in using persuasion and emphasis markers become the reason why they do not use those markers.

This research investigated the rhetorical reflected in the Introduction section of ten Acehnese students' undergraduate thesis by using Incecay framework. By looking the rhetorical pattern, the cross cultural rhetoric awareness will be identified. In the analysis, the researcher only focused on Background of the study in Introduction. The present study found some differences in Introduction section by Acehnese students. First is in the placement of 
the thesis statement which is put inductively by Acehnese students. Second is the pattern of idea of introduction section by Acehnese students maintained the circularity. The last is the use of metadiscourse markers. The students' awareness in using metadiscourse markers is not good enough to be considered. Consequently, they have to make an every effort to be accustomed in using metadiscourse markers. The result of this research shared that actually the Acehnese students mostly started the discussion in the general area to the specific one. It indicated that their thesis exhibit the inductive type of logic and circular thought of pattern.

\section{CONCLUSION}

This research comes up with a conclusion that most Acehnese students who wrote the Introduction section of undergraduate thesis established their rhetoric reflected in the Introduction section where the placement of the thesis statement and patterns of ideas is different with Native English Speaker (NES). Most Acehnese students' theses writing presented an inductive style and circular pattern of their English writing. To summarize, the answer of the research question showed that the rhetorical pattern used by the Acehnese students tends to be "Oriental Style". It refers to languages in Asia in which the communication is indirect. A topic is not addressed head on. Then, the Acehnese students still bring their first language convention when writing English. As a result, students' cross cultural rhetoric awareness is low. Admittedly, the analysis of the Introduction section has yielded the cultural uniqueness, which strengthens the significance of the study by contributing to cross-cultural rhetoric.

\section{BIBLIOGRAPHY}

Arsyad, S. (2000). The Indonesian and English Argument Structure: A Cross Cultural Rhetoric of Argumentative Text. Australian Review of Applied Linguistic, 22(2), 85-102.

Bennui, P. (2008). A study of L1 interference in the writing of Thai EFL students. Malaysian Journal of ELT Research, 4(2), 72-102.

Cahyono, B. Y. (2001). Research Studies in Second Language Writing and in Contrastive Rhetoric. Research Studies in Second Language Writing , 3(1), 39-52.

Cameron, C. (2007). Bridging the gap: working productively with ESL authors. Sci Ed, 30, 43-44.

Crawford, T., Mora Pablo, I., Goodwin, D., \& Lengelin, M. (2013). From contrastive rhetoric towards perceptions of identity: Written academic English in Central Mexico. Colombian Applied Linguistics Journal, 15(1), 9-24.

Estaji, M., \& Vafaeimehr, R. (2015). A comparative analysis of interactional metadiscourse markers in the Introduction and Conclusion sections of mechanical and electrical 
engineering research papers. Iranian Journal of Language Teaching Research, 3(1), 37-56.

Genc, B., \& Bada, E. (2005). Culture in language learning and teaching. The Reading Matrix, 5(1).

Hamadouche, M. (2013). Intercultural studies in the Arab world from a contrastive rhetoric perspective. Arab World English Journal, 2nd Special Issue on Translation, 181-188.

Helal, F. (2013). Discourse and Intercultural Acedemic Rhetoric. Journal of Modern Linguistic , 3(2), 149-156.

Hyland, K. (2012). Second Language Writing. New York: Cambridge University Press.

Incecay, V. (2015). Contrasting Rhetorical Patterns: Discovering Effects of First and Second Language Writing Convention. Eurasian Journal of Educational Research (61), 137154.

Kaplan, R. B. (1966). Cultural thought patterns in inter-cultural education. Language learning, 16(1-2), 1-20.

Li, M.-Y. (2011). A Contrastive Rhetoric Analysis of Internship Cover Letters Written by Taiwanense and Canadian Hospitality Majors. Macrothink Institute: International Journal of Linguistic, 3(1), 1-14.

Liu, J. J. (2007). Placement of the Thesis Statement in English and Chinese Argumentative Essays: A Study of Contrastive Rhetoric. Electronic Journal of Foriegn Language Teaching , 4(1), 122-139.

Magginson, D. (2007). The University of Ottawa. Retrieved 5 21, 2016, Writing Centre:http://www.ottawa.ca/academia/arts/writcent/bypergrammar.html

Marcellino, M. (2006). Probing Rhetorical Structures Of Advanced Learners' Expository Prose: A Data-Based Approach. IJELT, 2(2), 216.

Mirshami, A., \& Allami, H. (2008). Metadiscourse Markers in the Discussion / Conclusion Section of Persian and English Master's Theses. The Journal of Teaching Language Skill, 5(3), 23-40.

Nunan, D. (1999). Second Language Teaching and Learning. Boston: Heinle, Cengage Learning.

Rustipa, K. (2012). Ideas Development Patterns of English Expository Discourses By Indonesians as Reflected In the Jakarta Post. Jurnal Ilmiah Dinamika Bahasa dan Budaya, 7(1), 55-70.

Sabzevari, A., \& Sadeghi, V. (2014). A Contrastive Rhetorical Analysis of the News Reports in Iranian and American Newspapers. Iranian Journal of Research in English Language Teaching, 1(2), 12-19.

Samad, I.A \& Adnan, Z. (2017). Using A Genre-Based Approach to Prepare Undergraduate Students For An English Thesis Defence Examination: An Experimental Study to Address the 'Pedagogical Controversy'. Linguistik Indonesia Journal, vol 35 (1), 75 93

Swales, J. M., \& Feak, C. B. (2001). Academic Writing for Graduate Students:Essential Task and Skill. Ann Arbor: University of Michigan.

Xing, M., Wang, J., \& Spencer, K. (2008). Raising Students' Awareness of Cross-Cultural Contrastive Rhetoric in English Writing Via An E-Learning Course. Language Teaching and Technology, 12 (2), 71-93. 